\title{
Business Valuation of Islamic Banks in the Merger Plan to Become Indonesia's State-Owned Bank
}

\author{
Khulifa Ahdizia ${ }^{1}$, Dian Masyita ${ }^{2}$, Sutisna ${ }^{3}$
}

\begin{abstract}
Indonesia needs a sizeable Islamic bank to confront the ASEAN Economic Community (MEA) in 2020, so it can compete with existing Islamic banks in ASEAN. Then there was a plan to merge several Islamic banks into Government's Islamic banks. This study aims to analyze from the business valuation point of view about the Islamic bank's merger plan in Indonesia and to calculate the value of synergy if the bank merged. Company valuation used DCF-FCFE method and PBV. Islamic banks those were simulated merged are BSM, BRIS, and BNIS. Based on the study there is a synergy when the three banks merged. So, the merger plan of Islamic bank is feasible.
\end{abstract}

Keywords: Islamic banks, merger, valuation, synergy.

\begin{abstract}
Abstrak. Indonesia membutubkan bank syariah besar untuk menghadapi Masyarakat Ekonomi ASEAN (MEA) sehingga mampu bersaing dengan bank syariah yang ada di ASEAN. Kemudian muncul rencana untuk menggabungkan beberapa bank syariah menjadi Bank Syariah BUMN. Tujuan dari penelitian ini adalah untuk menganalisis dari sudut pandang penilaian bisnis mengenai rencana merger perbankan syariah di Indonesia dan untuk menghitung nilai sinergi apabila ketiga bank dimerger. Penilaian perusahaan menggunakan metode DCF-FCFE dan PBV. Bank syariah yang disimulasikan akan digabung adalah BSM, BRIS, dan BNIS. Berdasarkan hasil penelitian, adanya nilai sinergi ketika ketiga bank digabung. Maka, rencana merger bank syariah layak dilakukan.
\end{abstract}

Kata kunci: bank syariah, merger, valuation, sinergi.

\section{How to Cite:}

Ahdizia, K., Masyita, D., \& Sutisna. (2018). Business Valuation of Islamic Banks in The Merger Plan to Become Indonesia's State-Owned Bank. Etikonomi: Jurnal Ekonomi. Vol. 17 (2): 223 - 236. doi: http//dx.doi.org/10.15408/etk. v17i2.7238. 


\section{Introduction}

Indonesia is one of the countries with the largest Moslem population in the world. According to Indonesia's population census report in 2010, which held by the Central Bureau of Statistic (BPS) once in ten years, 87.18\% of populations in Indonesia are Moslem. This fact is an excellent potential for developing sharia economics in Indonesia. Based on the Global Report on Islamic Finance data in 2016, Indonesia ranked top 10 in the category of Islamic financial assets in 2013 with $\$ 13.00$ billion of total assets and the average growth from 2010 to 2014 is 29\% (Ernst and Young, 2016). The Asian Development Bank report of 2016 stated that Indonesia contributes $13.4 \%$ of all Islamic banking assets in Asia that reached \$209.3 billion (OJK, 2017). However, for countries in the Asian region, Indonesia's rank has a wide gap compared to Malaysia that occupies the second rank globally with \$156.7 billion of total assets.

The establishment of the Law on Islamic banking in Indonesia (Law Number 21 the year 2008) succeeds in increasing the number of Islamic banking industry players in this country. By the end of December 2016, there are 13 Islamic commercial banks (BUS), 21 Sharia Business Unit (UUS), 166 Sharia Rural Banks (BPRS) and 2.654 Islamic bank's offices operating in Indonesia (OJK, 2017). However, compared to the national banking industry, the market share of Islamic banks in Indonesia is still very low with only 5.33\% or Rp356.6 trillion by the end of 2016 .

One of the Financial Service Authority (OJK) main programs in Indonesia Islamic Banking Roadmap 2015-2019 is to strengthen the Islamic banking capital, business scale and efficiency with establishment state-owned Islamic bank or regional-owned Islamic bank. As the majority of Islamic banks in Indonesia still operate on a small scale of capital, they have difficulty in developing business activities and compete with other Islamic banks in ASEAN, such as CIMB Niaga and Maybank Syariah, to face the ASEAN Economic Community Integration (MEA).

To develop and to improve growth, the company can expand internally and externally. In internally, the company can do product development and innovation, expansion of operational area, the opening of a new branch and so on. While externally, companies can conduct a merger, acquisition, or consolidation strategies with other companies. Merger and acquisition activities become an essential alternative for external business expansion (Cartwright and Schoenberg, 2006). A merger is a combination of two or more companies, whereby the resulting company retains the identity of one company, usually more massive (Gitman and Zutter, 2015) or a combination of two companies where only one company survives while the other is no longer operating (Gaughan, 2007). Consolidation differs from the merger. Consolidation is a combination of two or more companies into one new company (Gitman and Zutter, 2015). The difference between consolidation and merger is related to the company itself. In consolidation, if two or more companies joined, it will create a new company. On the other hand, a merger between two or more companies will create only one company exists.

The merger of four state-owned banks in Indonesia in 1998 into Bank Mandiri 
succeeds being one of the banks with the most significant asset in Indonesia. Recorded from 2010 until the end of December 2016, there are 17 merger and acquisition activities in the banking sector (KPPU, 2017). Merger and acquisition activities in the banking industry can integrate all banking sectors to be more competitive and efficient (Shanmugam and Neir, 2003).

In general, through merger and acquisition activities, companies expected could do several advantages. First, creating synergies. Second, increase the market share. Third, growth or diversification of products. Fourth, increasing revenue. Fifth, the merger will reduce the cost. Sixth, increasing fund. Seventh, protecting markets by weakening or eliminating rivals. Eighth, obtain the product or technology. Ninth, tax consideration. Tenth, strengthen core business by expanding the most competitive areas. Eleventh, obtaining positions in other countries or continents and achieve critical mass or competitive size (Bohlin et al. (2000), DePamphilis (2011), and Gitman and Zutter (2015)). Hoberg and Philipp (2010) stated that synergy in the product is one of the critical drivers of the merger. Mergers tend to be done on companies that have similar products and can complement each other. Also, mergers will create higher value if it did on a company which is a competitor in the same industry or merger horizontally (Barnile, et al., 2011).

Synergy can occur when the value of the merged company is greater than the value of acquiring the company and the value of the acquired company when it is standalone (Ross et al., 2012). According to Kartika and Rofi (2015), financial and operational synergies that may achieve from the merger of a bank are improved in facilities, increased customers more than employee growth, increased revenues, strengthen capital access and increased potential market value.

Lommerud, et al. (2006) study shows that Islamic banks that do mergers and acquisitions have two main reasons. First, the achievement of scale economies caused by increased synergies between Islamic banks involved in mergers and acquisitions. Second, merger and acquisition activities can change the market structure that can affect the profitability of Islamic banks.

Natt et al. (2007) in Kandil and Chowdury (2014) states that mergers and acquisitions are significant for Islamic banks to grow quickly and profitably because they can create economies of scale or scope so that firms can have better access to capital markets then decrease costs of capital as a financial benefit. Therefore, According to Kandil and Chowdury (2014), ROI and ROE on the merger and acquisition of Islamic banks are higher than conventional banking. Furthermore, Mahmood et al. (2012) in Kandil and Chowdury (2014) in his research on Islamic banks in Pakistan showed significant evidence of the primary objectives of Islamic banking business sector in mergers and acquisitions is to enlarge synergies. The merger and acquisition activities of the Islamic banking sector considered more on the macroeconomic level compared to microeconomics.

However, according to Hitt et al. (2012), M\&A strategy can be successful, but sometimes create a little or no value. It happened cause of company unable to create 
synergy, too high premium paid, selecting improper targets, and process integration that non-effective. So, before M\&A transaction, stakeholders need specific information about business continuity, projects, strengths, and weaknesses of target companies that were merged or acquired. The Due diligence process is required to minimize the risk of failure in such expansion activities. The valuation is an integral part of financial due diligence, where financial due diligence is in the fourth phase of the 5 (five) stages of due diligence activity that includes strategic decisions, commercial due diligence, operational due diligence, financial due diligence, and legal due diligence (Haas and Hodgson, 2013). Value of company used to determine the financial performance and company's welfare for a long-term (Deev, 2011). The valuation of a bank is an estimate of its market value regarding money on a specific date taking into accounts the expected risk factors, time, and earnings (Deev, 2011).

This paper aims to calculate and to analyze the value of company and value of synergy using DCF-FCFE and Relative valuation methods if Islamic bank merger plan happened. These studies do before the M\&A process occurs. Most of the previous studies analyzed after M\&A occurred. This paper continues discussing simulated merger plan in the banking industry that had been studied before by Kartika and Rofi (2015).

The Islamic banks that simulated being a target of bank merger are Bank Syariah Mandiri (BSM), Bank Rakyat Indonesia Syariah (BRIS), and Bank Negara Indonesia Syariah (BNIS). BSM is a subsidiary state-owned bank of Bank Mandiri, one of the biggest banks in Indonesia. BRIS is a subsidiary of the biggest micro banking state-owned bank in Indonesia. BNIS is a subsidiary of the oldest and the first state-owned banks in Indonesia, Bank Negara Indonesia (BNI).

The results of this study expected to use as a source of information and contribution of thoughts in practice on business valuation before merger and acquisition occurred. It also expected as a source of input for the stakeholder's future decisions or policies.

\section{Method}

This research is quantitative descriptive research, which aims to calculate the value of the firm and the value of synergy if the company merged. The valuation methods used in this study are Discounted Cash Flow - Free Cash Flow to Equity and Relative Valuation - Price to Book Ratio. This method used because the companies are banking sector that classified to the financial services industry. Thus the capital structure is different from other companies in general. In the banking sector, the capital structure consists only of the cost of equity. There is no cost of debt because the bank is an intermediary institution that the liabilities or debt position is a third party fund or deposits from banks' customers. Furthermore, in banks, operational and financing decisions cannot be separated since interest, and expense income (part of financing decisions) is an essential element in bank operating income (Anggelopoulos, 2017). So, in preparing cash flows for banks, the method of valuation of Equity Cash Flow should be used (Anggelopoulos, 2017). This measurement is the most valid calculation method used in valuing the bank and also reflecting the fact that the bank can create value 
regarding liabilities recorded on the balance sheet of financial statements (Deev, 2011). Cash Flow to Equity calculation for the banking industry according to Anggelopoulos (2017) as follows:

Cash Flow to Equity = Net Income + Depreciation - Net Increase in Loans - Net Increase in Securities and Investments - Net Increase in Amounts due from banks - Net Capital Expenditure + Net Increase in Deposits + Net Increase in Interbank Funds ....

In the relative valuation approach, observing how the market price of the same entity or in the same industry will do asset valuation. In this approach, the value of an asset or entity derived from a comparable or similar asset price then standardized using a common variable (Damodaran, 2012). Research conducted by Liu, et al. (2002) shows that the valuation calculated from several industries based on earnings report is closer to market prices compared to operating cash flows report. In this study, the relative valuation method was proxied by Price to Book Value (PBV) with the following calculation formula:

PricetoBookRatio $=\frac{\text { MarketValuetoEquity }}{\text { BookValuetoEquity }}$

The formula to value a synergy according to Ross, et. al. (2012) is:

Synergy $=\mathrm{V}_{\mathrm{AB}}-\left(\mathrm{V}_{\mathrm{A}}+\mathrm{V}_{\mathrm{B}}\right)$

where,

$\mathrm{V}_{\mathrm{AB}}=$ company value when combined

$\mathrm{V}_{\mathrm{A}}=$ Firm value $\mathrm{A}$

$\mathrm{V}_{\mathrm{B}}=$ Firm value $\mathrm{B}$

The objects of this research are Islamic commercial banks which are a subsidiary of state-owned banks in Indonesia. Those are Bank Syariah Mandiri (BSM), BNI Syariah (BNIS), and BRI Syariah (BRIS). The secondary data will use to analyze and to calculate the company value. The secondary data will be gained from the banks' annual report year 2011 until 2016, Damodaran's risk premium, beta stock Pefindo, and other published information to support the analysis.

\section{Result and Discussion}

\section{Result}

Indonesia's economic growth over the past 6 (six) years has continued to slow down. From 2011 to 2015, Indonesia's economic growth rate has decreased. However, in 2016, Indonesia's economic growth increased by $0.23 \%$ to $5.02 \%$ from the previous year which only reached $4.79 \%$. The inflation rate in 2016 was $3.02 \%$, which is still under the government's target of $4 \% \pm 1 \%$. Over the past six years, this year's inflation rate has been the lowest. Meanwhile, by the end of 2016, the exchange rate of the Rupiah against the Dollar strengthened by IDR 359.00 compared to the same period in 2015. The BI Rate by the end of the 2016 period stood at 4.75\%. In 2016, Bank Indonesia issued the latest policy regarding the determination of the BI Rate to strengthen the monetary operation 
framework. The new policy is to apply for the BI Rate 7-Day Repo Rate effective from August 19, 2016.

Islamic banking assets in Indonesia for the last six years continued to grow. The period 2014 until 2016 was a tough year for the Indonesian banking industry and Islamic banking industry. Over the last three years, the average growth of Islamic banks was $13.90 \%$, which is lower than 2011 to 2013 with an average growth of $35.63 \%$. Slowing growth in Islamic banking was a result of slowing domestic and global economic developments in 2014-2015.

Although the growth rate slowed down from 2012 to 2015, Islamic banking assets gained significant growth in 2016, amounting to $20.28 \%$ or IDR 61.6 trillion to IDR 365.6 trillion from the previous year about Rp304 trillion. Even so with the deposit funds that collected by the Islamic banks increased from 20.84\% or IDR 49.2 trillion in 2015 to IDR 285.2 trillion in 2016. Financing disbursed by the Islamic banks throughout the year 2016 grew by $16.41 \%$ or Rp35.9 trillion to Rp254.7 trillion in 2016 compared to 2015 of Rp218.72 trillion.

The decline in asset growth has caused the market share of Islamic banks to be far from the target set by Bank Indonesia in 2007, which is 5\% market share in 2008 and 15\% in 2015. However, the increase in market share in 2016 was the highest over the last five years, which the market share of Islamic banks increased by about $0.45 \%$ in 2016 .

The highest increase of Islamic banking assets in 2016 was triggered by the conversion of Bank of Aceh from conventional to sharia in September 2016. Bank of Aceh assets of IDR 18.95 trillion or $5.18 \%$ of the total assets of Islamic banking contributed for increase assets of national Islamic banking. The conversion of Bank of Aceh Syariah was able to reduce the dominance of the composition of national banking assets that previously dominated by BSM and Bank Muamalat in 2015 about $42.48 \%$ to $36.84 \%$ in December 2016 (OJK, 2017).

In general, bank valuation method is complicated and less studied. Various valuation techniques used in practice, but no single method dominates. This fact is because each approach involves a variety of advantages and disadvantages (Deev, 2011). The premise in bank valuation does not only recognize the difference of theoretical and applicative valuation methods, but detailed knowledge of bank activities is also required to adjust the valuation model through the subject of the specific context in the analysis (Franceschi, 2008).

The valuation of three banks (BSM, BRIS, and BNIS) used two-stage DCF-Free Cash Flow to Equity which assumes that the cash flow received by the company will grow with a specific growth rate over a specified period then the growth rate will be timeless constant. Relative Valuation-Price to Book Value used to compare company's value with banking companies that listed at Indonesia Stock Exchange.

The calculation of the cost of equity that will be discounted factor in FCFE calculation is as follows: First, a risk-free rate used SUN FR0056 series with rate 8,375\%. Second, risk premium based on total equity risk premium Damodaran for Indonesia is 
$7.62 \%$. Third, the beta calculation for each company shows at table 1 using the bottomup beta method.

Table 1. Company Beta Valuation

\begin{tabular}{|c|c|c|c|c|c|c|c|c|}
\hline \multirow[b]{2}{*}{ FIRM } & \multirow[b]{2}{*}{ BETA } & \multirow{2}{*}{$\begin{array}{l}\text { BSM } \\
\text { DER }\end{array}$} & \multirow[b]{2}{*}{ FIRM } & \multirow{2}{*}{\multicolumn{2}{|c|}{$\begin{array}{l}\text { BRIS } \\
\text { DER }\end{array}$}} & \multirow[b]{2}{*}{ FIRM } & \multirow[b]{2}{*}{ BETA } & \multirow{2}{*}{$\begin{array}{c}\text { BNIS } \\
\text { DER }\end{array}$} \\
\hline & & & & & & & & \\
\hline BMRI & 1.587 & 5.46 & BBRI & 1.530 & 5.66 & BBNI & 1.684 & 5.53 \\
\hline PNBS & 0.717 & 6.34 & PNBS & 0.717 & 6.34 & PNBS & 0.717 & 6.34 \\
\hline BBTN & 1.456 & 9.88 & MCOR & 0.606 & 4.06 & INPC & 0.556 & 4.84 \\
\hline BTPN & 0.645 & 4.25 & INPC & 0.556 & 4.84 & BSIM & 0.639 & 5.84 \\
\hline BBKP & 0.611 & 9.90 & BBTN & 1.456 & 9.88 & BBTN & 1.456 & 9.88 \\
\hline \multirow[t]{5}{*}{ Average } & 1.038 & 5.46 & Average & 0.973 & 6.16 & Average & 1.010 & 6.49 \\
\hline & DER BSM & 11.16 & & DER BRIS & 9.65 & & DER BNIS & 10.19 \\
\hline & Tax Rate & $25 \%$ & & Tax Rate & $25 \%$ & & Tax Rate & $25 \%$ \\
\hline & Unlevered & 0.157 & & Unlevered & 0.173 & & Unlevered & 0.172 \\
\hline & Levered & 1.475 & & Levered & 1.426 & & Levered & 1.488 \\
\hline
\end{tabular}

Source: Pefindo and the financial statements of each company (data processed)

Fourth, after calculated beta for each company, then calculates cost of equity using CAPM model. The calculation cost of equity of each bank can be seen in Table 2 .

Table 2. Calculating Cost of Equity (ke)

\begin{tabular}{ccccc}
\hline Company & Beta $(\beta)$ & RP & Ke \\
& 1 & 2 & 3 & $4=(1+(2 * 3))$ \\
\hline BSM & $8.375 \%$ & 1.475 & $7.62 \%$ & $19.61 \%$ \\
BRIS & $8.375 \%$ & 1.693 & $7.62 \%$ & $19.25 \%$ \\
\hline
\end{tabular}

Source: Data processed

Before projecting cash flows, calculating estimated income growth as the basis for calculating cash flows by the Compound Annual Growth Rate (CAGR) method over the historical period (2011-2016) was a first thing to do. The company's revenue derived from the company's operating income through its core business activities, such as revenue sharing, sales revenue (from murabahah financing), revenue from ijarah financing. Besides that, the 
revenue also comes from other significant revenues, like profit-sharing dividends, revenue from Sharia Indonesian Bank Certificate, revenue sharing from other bank placement, administrative income and other incomes which related to the bank's core operational activities.

Based on the calculation, the historical average revenue growth of each company is 7.16\% for BSM, $16.12 \%$ for BRIS and $21.15 \%$ for BNIS. The high revenue growth of BRIS and BNIS due to those banks had spun off in 2008 and 2009, so both companies are in a growing condition while BSM is in a stable growth because the bank has operated since 1999. Based on the historical average growth, e projected revenue of each company for the next five years (2017-2021) could also be calculated.

Components for calculating FCFE consists of earnings before interest and tax (EBIT), depreciation and amortization, the net increase in loans, the net increase in securities and investments, net increase in amounts due from banks, capital expenditure, the net increase in deposits and a net increase in interbank funds. Each FCFE's component calculated based on that average proportion historically to total revenue each year then the proportion of each account used to project future FCFE.

Table 3. Company Valuation (Billion Rupiah)

\begin{tabular}{|c|c|c|c|c|}
\hline Company & Total PV of FCFE & $\begin{array}{l}\text { Value of } \\
\text { Company }\end{array}$ & $\begin{array}{l}\text { Total Shares } \\
\text { (full amount) }\end{array}$ & $\begin{array}{l}\text { Value of Company per share } \\
\text { (in IDR) }\end{array}$ \\
\hline \multicolumn{5}{|c|}{ Pessimist Scenario } \\
\hline BSM & $7,653,990$ & $8,740,558$ & $397,804,387$ & $21,972.00$ \\
\hline BRIS & $2,017,709$ & $2,335,814$ & $3,958,000,000$ & 590.15 \\
\hline BNIS & $1,685,719$ & $1,845,631$ & $1,501,500$ & $1,229,192.69$ \\
\hline \multicolumn{5}{|c|}{ Moderate Scenario } \\
\hline BSM & $7,911,433$ & $8,998,002$ & $397,804,387$ & $22,619.16$ \\
\hline BRIS & $2,919,265$ & $3,237,370$ & $3,958,000,000$ & 817.93 \\
\hline BNIS & $2,919,538$ & $3,079,450$ & $1,501,500$ & $2,050,915.55$ \\
\hline \multicolumn{5}{|c|}{ Optimist Scenario } \\
\hline BSM & $10,125,283$ & $11,211,852$ & $397,804,387$ & $28,184.33$ \\
\hline BRIS & $3,149,947$ & $3,468,052$ & $3,958,000,000$ & 876.21 \\
\hline BNIS & $2,965,218$ & $3,125,130$ & $1,501,500$ & $2,081,338.74$ \\
\hline
\end{tabular}

Source: data processed

Free cash flow to equity calculated based on previously established assumptions and determined proportion of FCFE components, the company's cash flow calculation and the 
valuation of the value of equity shows in Table 3. Based on the FCFE calculation in Table 3, the operational profit (EBIT) projected to grow over the next five years by historical revenue growth, and in the sixth year onwards the company expected going concern with a growth rate of 5.02\% (Indonesia's economic growth in 2016). The company's cash flow projected to increase in line with increases operating profit. Then total FCFE discounted by the cost of equity to calculate the present value of the projected cash flow. In calculating the value of the company, total FCFE that has been discounted by the cost of equity, amounted with company's cash per December 31st, 2016. Value per share obtained by dividing the value of the company with a number of the company's shares. The company valuation using DCFFCFE method can conclude that the value of BSM is in the range of IDR 8.74 trillion to IDR 11.21 trillion. The value of BRIS is in the range of Rp2.34 trillion to IDR 3.47 trillion. The value of BNIS is in the range of IDR 1.84 trillion to IDR 3.13 trillion. BNIS per share had a high value because of a small number share and BNIS book value per share about IDR 1 billion.

Values of three companies amounted to obtain the value of the combined company without synergy (Ross et al., 2012). The result showed that the value of bank merger's without synergy is IDR 15.31 trillion (moderate scenario). After the value of each company has known, the next step is calculating the PBV ratio. It shows in Table 4.

Table 4. PBV Calculation

\begin{tabular}{cccc}
\hline Company & Pessimist & Moderate & Optimist \\
\hline BSM & 1.367 & 1.408 & 1.754 \\
BRIS & 0.931 & 1.290 & 1.382 \\
BNIS & 0.742 & 1.238 & 1.257 \\
\hline
\end{tabular}

Source: data processed

Based on IDX statistics in 2016, it is known that the average PBV of the banking industry which listed on Indonesia Stock Exchange (IDX) in 2016 was 1.53 with the lowest PBV was 0.28 (PT Bank Artha Graha International Tbk.) and the highest PBV was 5.45 (PT BPD Banten Tbk.). Based on table 4, PBV of three companies is within PBV in banking industry range, which means fair. The lowest PBV of three companies is still above the lowest PBV in the banking industry, and its highest didn't exceed the highest PBV in the banking industry.

Next step is calculating the value of synergy with the following stages: First, Growth bank merger is assumed to be the average growth of each company if it is stand-alone. The average growth is $14.81 \%$. Meanwhile, the growth terminal is assumed to be $5.02 \%$ (Indonesia's economic growth rate in 2016). Second, the beta of bank merger calculated using bottom-up beta formula. The Beta of BSM, BRIS, and BNIS being a comparative beta. The calculations are shown in Table 5. 
Table 5. Bank Merger's Beta Calculation

\begin{tabular}{lcc}
\hline Company & BETA & DER \\
\hline BSM & 1.475 & 11.23 \\
BRI Syariah & 1.427 & 9.65 \\
BNI Syariah & 1.488 & 10.80 \\
Average & 1.463 & 10.56 \\
DER Bank Merger & & 10.48 \\
Tax Rate & & $25 \%$ \\
Unlevered & & 0.164 \\
Levered & & 1.453 \\
\hline
\end{tabular}

Source: data processed

Third, after beta of bank merger known, then calculate the cost of equity using the CAPM model. The assumption of risk-free rate and risk market used is the same as used in the calculation of CAPM for each bank when it is stand alone, i.e., 8.375\% (risk-free rate) and $7.62 \%$ (risk premium). The calculation is as follows:

$$
\begin{aligned}
& \left.\mathrm{CAPM}=\mathrm{Rf}+\left(\beta^{*} \mathrm{Rp}\right)\right) \\
& \mathrm{CAPM}=8.375 \%+(1.453 *(7.62 \%)) \\
& \mathrm{CAPM}=19.45 \%
\end{aligned}
$$

Fourth, the results of the bank merger's valuation shows in Table 6. The result of the bank merger valuation showed that there is a synergy in a pessimistic, moderate and optimistic scenario. When calculated using the PBV method, the bank merger's PBV is 1.525 (pessimist), 2.063 (moderate) and 2.269 (optimist). Bank merger's PBV in the moderate and optimistic scenario is above the average PBV of the banking industry that listed in Indonesia Stock Exchange. It means that the value of a merged bank is above the average value of the

\begin{tabular}{|c|c|c|c|c|}
\hline Scenario & Scenario & Pessimist & Moderate & Optimist \\
\hline Value of Bank Merger & & $17,367,567$ & $23,490,225$ & $25,843,167$ \\
\hline Value of Combination & & $12,922,003$ & $15,314,822$ & $17,805,034$ \\
\hline Value of Synergy & & $4,445,564$ & $8,175,403$ & $8,038,133$ \\
\hline PBV & & 1.525 & 2.063 & 2.269 \\
\hline Equity Book Value & & $11,389,017$ & & \\
\hline
\end{tabular}
banking industry with fair value.

Table 6. Value of Synergy (Billion Rupiah)

Source: data processed 


\section{Discussion}

BSM's total assets by the end of 2016 are the highest compared to BRIS and BNIS amounting to IDR 78.83 trillion or $21.56 \%$ of total national Islamic banking asset. A total asset of BRIS is amounting to IDR 27.69 trillion or $7.57 \%$ of total national Islamic banking asset. BNIS's total asset is worth IDR 28.31 trillion or $7.74 \%$ of total national Islamic banking asset. If the three banks were merged, the total assets of the merged banks will be IDR 134.83 trillion or have a market share of $36.88 \%$ of total national Islamic banking asset.

The merger of three banks could strengthen their capital structure. Strong capital structure creates a bank to be able for optimizing its business activities. Total equity owned by BSM in last December 2016 is IDR 6.39 trillion which categorized BSM in BUKU (Commercial Bank Group of Business) 3, a bank with a minimum capital of IDR 5 trillion. On the other hand, BRIS and BNIS categorized in BUKU 2 with total equity of each bank are IDR 2.51 trillion and IDR 2.47 trillion. If all of three banks merged, the total capital owned would become IDR 11.39 trillion, and it is still in the category of BUKU 3. This amount of capital is not enough to categorize in BUKU 4, which the minimum capital is IDR 30 trillion. To achieve the total capital of IDR 30 trillion, it requires additional capital of IDR 18.61 trillion. If bank merger will become a state-owned bank and categorized in BUKU 4, the Government should give capital injection around IDR 18.61 trillion. Thus, Government's ownership in bank merger will amount $62.1 \%$.

If the bank merged, it would increase potential market value. With increasing in the capital, it is easier for banks to increase the ability in expanding their business activities through product development and operational areas to compete with other companies (Kartika and Rofi, 2015). Furthermore, the total deposit funds of bank merger will become IDR 116.2 trillion or $40.74 \%$ of total national Islamic banking deposits. Besides that, the provided financing position (PYD) if three banks merged, will become IDR 94.09 trillion or equal to $36.94 \%$ of total national Islamic banking PYD.

Miftah and Wibowo (2017) said that a merger could be one of the strategies to accelerate the Islamic banking industry. To improve competitiveness and to be able to compete globally, the discourse of merger of three Islamic banks is feasible to realize. It is because Indonesia has a potential value that can develop from the Islamic banking industry. Problems that may arise when the three banks merged are managerial issues. Strategic position within the company will decrease and differences corporate culture of each origin company can cause a collision.

Valuation is one of the stages in the due diligence process, in which the implementation of due diligence do before merger and acquisition transactions. The implementation of due diligence involved various aspects, including financial, legal, human and operational (Tan, 2015). Proper implementation of due diligence means digging up direct information about the target company which covers customers, competitors, costs, and capabilities. Interviewing directly to customers and competitors should do this activity. The results of this activity will help the company several pieces of information. First, to obtain accurate information regarding the size and the growth rate of the target company's market. Second, how the 
target company's position among competitors in market shares, revenue, and profit in each segment. Third, the all aspects of cost efficiency and the competitor initiatives. Fourth, the competencies, capabilities, and technologies that will be available to new companies when it has been merged (anonymously, 2004). Furthermore, according to Denison \& Ko (2016), to helps organizations or companies manage their culture during M\&A process, culture due diligence is essential being done at an early stage beside financial and strategic assessment.

\section{Conclusion}

Based on research result and discussion, it can conclude that by the DCF-FCFE method, resulted of BSM value is IDR 8.99 trillion, the value of BRIS is IDR 3.23 trillion, and the value of BNIS is IDR 3.08 trillion. The PBV values of BSM, BRIS, and BNIS in the moderate scenario are 1.408; 1.290 ; and 1.238. The value result is below the average PBV of the banking industry which listed in Indonesia Stock Exchange in 2016 but still higher than the lowest PBV among the banking industry in Indonesia Stock Exchange. Valuation of bank merger using the DCF-FCFE method is Rp23.49 trillion and its combined value about Rp15.31 trillion. Therefore, the value of synergy is IDR 5.89 trillion.

Some recommendation based on the result is improving coor $\mathrm{d}$ ination between Government and OJK not only in realizing merger plan of Islamic bank but also in other aspect and policy that supports the development in Islamic banking industry. Thus, this sector is expected to grow more rapidly and could compete globally in the future. The merger of Islamic banks is still a discourse, and there has been no official decision from the Government or the stakeholders. So, they should review this merger plan. If the merger of these three banks realized, then the due diligence to minimize the risk needs to be done. Stakeholders and governments should consider other aspects when the merger plan realize. The limitation of this study is only valuing synergy if Islamic bank being merged and analyze through business valuation point of view. For future research, a researcher can analyze from others points of view, such as legal, Government's policy, customers, shareholders, and society perceptions, and so forth.

\section{References}

Anggelopoulos, E. (2017). Understanding Bank Valuation: An Application of the Equity Cash Flow and the Residual Income Approach in Bank Financial Accounting. Open Journal of Accounting. Vol. 6: 1-10. doi: https://doi.org/10.4236/ojacct.2017.61001.

Anonimously. (2004). Getting Growth Right: How Due Diligence Aids Successful Mergers. Strategic Direction. Vol. 20(10): 11-14. doi: https://doi.org/10.1108/ 02580540410562107

Bernile, G., Lyandres, E., \& Zhdanov, A. (2011). A Theory of Strategic Mergers. Review of Finance. Vol. 16: 517-575.

Cartwright, S., \& Schoenberg, R. (2006). Thirty Years of Mergers and Acquisitions Research: Recent Advances and Future Opportunities. British Journal Management. Vol. 17(S1): S1-S5. doi: https://doi.org/10.1111/j.1467-8551.2006.00475.x. 
Damodaran, A. (2012). Investment Valuation: Tools and Techniques for Determining the Value of Any Asset ( $3^{\text {rd }}$ Ed). New Jersey: John Wiley \& Sons, Inc.

Deev, O. (2011). Methods of Bank Valuation: Critical Review. Journal of Financial Assets and Investing. Vol. 3: 33-44.

Denison, D. R., \& Ko, I. (2016). Cultural Due Diligence in Merger and Acquisition. Advances in Merger and Acquisitions, Vol. 15: 53-72.

DePamphilis, D. (2011). Mergers and Acquisitions Basics: All You Need to Know. Oxford: Elsevier.

Franceschi, L. F. (2008). Valuations of Banks in Mergers. Academic Affiliation Catholic University of Milan.

Gaughan, P. A. (2007). Merger, Acquisitions, and Corporate Restructurings', 5th Edition. New Jersey : John Wiley and Sons, Inc.

Gitman, L. J. \& Zutter, C. J. (2015). Principles of Managerial Finance (14th Ed). Boston: Prentice Hall.

Hitt, M. A., King, D. R., Krishnan, H., Makri, M., \& Schijven, M. (2012). Creating Value through Mergers and Acquisitions: Challenges and Opportunities. In Faulkner, D., Teerikangas, S., \& Joseph, R. J. (eds). The Handbook of Merger and Acquisitions. Oxford: Oxford University Press.

Hoberg, G., \& Phillips, G. (2010). Product Market Synergies and Competition in Mergers and Acquisitions: A Text-Based Analysis. The Review of Financial Studies. Vol. 23 (10): 3773-3811. doi: https://doi.org/10.1093/rfs/hhq053.

Kandil, T., \& Chowdury, D. (2014). Islamic Banks' Mergers and Acquisitions - Impacts on Performance and Financial Crisis in the United Kingdom. Contemporary Studies in Economic and Financial Analysis. Vol. 95: 119-140.

Kartika, L., \& Rofi, M. A. (2015). Simulasi Strategi Akuisisi Bank di Indonesia: Akuisisi Bank Mandiri Terhadap Bank Tabungan Pensiunan Nasional (The Strategy Simulation of Bank's Acquisition in Indonesia: The Acquisition of Bank of Mandiri to Bank of Tabungan Pensiunan Nasional). Finance and Banking Journal. Vol. 17(2): 26-51.

Liu, J., Nissim, D., \& Thomas, J. (2002). Equity Valuation Using Multiples. Journal of Accounting Research. Vol. 40(1): 135-172.

Lommerud, K. E., Olsen, T. E., \& Straume, O. R. (2006). Cross Border Merger and Strategic Trade Policy with Two-Part Taxation: Is International Policy Coordination Beneficial?. WZB Discussion Paper, No. SP II 2006-24.

Mahmood, I., Aamir, M., Hussain, M., \& Sohail, N. (2012). Impact of Merger/Acquisition on Share Price-a case Study of Pakistan. European Journal of Scientific Research. Vol. 67(4): 617-624.

Miftah, K., \& Wibowo, H. (2017). Merger and Industrial Acceleration: Study at Indonesian Islamic Banking Industry. Signifikan: Jurnal Ilmu Ekonomi. Vol. 6 (1): 29-48. doi: https://doi.org/10.15408/sjie.v6i1.4728. 
Khulifa Ahdizia. Business Valuation of Islamic Banks in the Merger Plan to Become Indonesia's

Ross, S. A., Westerfield, R. \& Jaffe, J. F. (2012). Corporate Finance. New York: The McGrawHill Companies.

Shanmugam, B., \& Nair, M. (2003). Mergers and Acquisition of Banks in Malaysia. Managerial Finance. Vol. 30(4): 1-18.

Tan, W. (2015). Pentingnya Due Diligence Sebelum Berinvestasi (The Importance of Due Diligence Before Investing). Wake Up Call RSM AAJ Associates, accessed at www.rsm. global on June $19^{\text {th }}, 2017$. 